\title{
THE RELEVANCE OF EVOCATION AND REFLECTION CARDS IN the LEARNING PROCESS
}

PROBLEMS

OF EDUCATION

IN THE $21^{\text {st }}$ CENTURY

Volume 41, 2012

\author{
Sirje Piht, Piret Lehiste \\ Tallinn University Haapsalu College, Haapsalu, Estonia \\ E-mail: sirje@hk.tlu.ee, piret@hk.tlu.ee
}

Rea Raus

Tallinn University, Tallinn, Estonia

E-mail: rearaus@tlu.ee

Mariliis Lazarev

Salme Basic School, Salme, Estonia

E-mail: mariliis.lazarev@mail.ee

\begin{abstract}
When starting school, most students have a desire to learn and are motivated to participate actively in the learning process. Lack of interest is what undermines learning. Research on children's well-being in the European Union (EU), conducted at York University in 2006, indicated that Estonia stands out among 25 EU countries with the lowest level of students who enjoy school and have a feeling of well-being. However, the results of 2006 and 2009 PISA (Programme for International Student Assessment) research indicate that Estonian students do have good subject knowledge and study skills.

The Estonian Human Development Report 2009 states that 70\% of Estonian students consider their study load too heavy, 67\% feel fatigue and 33\% do not want to go to school at all. The report indicates that schools do not pay enough attention to personality development, analysis and discussion (Eesti Koostöö Kogu, 2010). Based on the results of the above-mentioned research, it can be said that Estonian students have good subject knowledge, but learning offers them neither pleasure nor interest (Organisation for Economic Cooperation and Development [OECD], 2007; Puksand, Lepmann \& Henno, 2010).

The key question for this research was how learner-centered goal setting and reflection support the learners' skills to set their own goals for the learning process and to analyze it. Learners are interested in the learning process in case they understand the goals, are actively involved, and take responsibility for their actions. Learners should experience success and get immediate feedback on their activities.

Ninety-six different evocation and reflection cards were tested by 24 Estonian teachers in the spring of 2011. The purpose of testing was to clarify how effective the usage of evocation and reflection cards is in supporting students in setting goals and analysing their activities. The quantitative research method (in the form of a questionnaire) was used in order to discover teachers 'personal opinions, attitudes and approach to the cards and make conclusions about the relevance of the cards in supporting students' involvement in the evocation and reflection phase of learning.

The research results showed that giving and receiving feedback develop students'self-image, motivate them to participate in the learning process and develop their study skills. The relevance of evocation and reflection cards depends greatly on a teacher's opinion and will to use them. If a teacher does not possess enough knowledge about how to involve students in goal setting and analysis of the lesson, the efficiency of these cards is not evident.
\end{abstract}

Key words: evocation, learning motivation, reflection. 


\section{PROBLEMS \\ OF EDUCATION \\ IN THE $21^{\text {st }}$ CENTURY \\ Volume 41,2012 \\ Introduction}

The Swiss psychologist Jean Piaget demonstrated that "we learn by making sense of the world in terms of the concepts we already have. In the process of making sense of the world, we change our old concepts, and thus expand our capacity for making even more sense of our future encounters with the world" (Crawford, Mathews, Makinster \& Saul, 2005, p.2). Based on Piaget's theory, in modern pedagogy a lesson is divided into three phases: Evocation, Realization of Meaning and Reflection (Steele, Meredith, Temple \& Walter, 1998). This threephase model was earlier called "Anticipation, Realization, and Contemplation" by Joseph Vaughn and Thomas Estes (1986).

The experiential learning cycle, developed by David A. Kolb (1984), is also based on the belief that in-depth learning (learning for real comprehension) comes from a sequence of experience and reflection. He states that, "learning is the process whereby knowledge is created through the transformation of experience" (p.38).

For effective learning, students should be actively involved in every phase of the lesson. To support motivation, evocation is essential because it is a pre-condition for thoughtful and effective work during the whole lesson: it helps to concentrate the attention of students, arouses their curiosity and interest, and also motivates them to participate actively in the lesson (Gagné \& Driscoll, 1992).

Reflecting means both mirroring and contemplation. Reflection enables us to understand and assess our experience. The final goal of reflection is learning - when reflecting, a person stops to analyse the results of his/her actions and level of skills or he/she acknowledges deeper values and beliefs that form the basis of his/her activities (Poom-Valickis, 2007).

The following is an overview of evocation and reflection and their importance in the learning process, as well as different forms of feedback.

\section{Theoretical Aspects of the Relevance of Evocation in the Learning Process}

"When a teacher can effectively evoke students to learn a new topic, a key to success is in his/her pocket already. If there is no evocation key, you must break the lock, i.e. the student's soul, with force - and it is surely a far more difficult task" (Õunapuu, 2003, p.12).

Evocation guarantees that students start working. In the initial phase of learning, raising interest towards a problem or a topic is more important than the transfer of knowledge, because interest plays an important role in the development of learning motivation (Kidron, 1999; Krull, 2000; Steele et al., 1998). Evocation at the beginning of a lesson is often underestimated because there is a tendency to think that students come to school to study. In some cases this is true, but there are students who need to be "lured" to learn by arousing their interest, setting goals and raising expectations (Klooster, Steele \& Bloem, 2001).

Teaching should begin with goal setting, because if we cannot define the changes that should become evident in the student's physical, psychological and social development, there is no pedagogical activity involved (Liimets, 1998). According to Gagné \& Driscoll (1992) setting goals for the lesson helps to increase motivation, which is a pre-condition for learning. According to Krull (2000) it is important to consider the following while setting goals:

- $\quad$ try to set a few important goals rather than too many less important goals;

- do not exaggerate behavioural terms when setting learning goals;

- avoid strict precision in meeting the learning goals.

The expectations and goals that we set should be realistic and achievable because if they are not achievable, students will constantly experience failure and lose motivation (Mathews, Löfström \& Poom-Valickis, 2008). When concrete goals are achievable and open the way to 
achieve even greater goals, the student is willing to make an effort until the goal is reached. Activities that are meaningless to students are not productive even if they are well prepared (Gagné \& Driscoll, 1992; Pollard \& Triggs, 2001).

It is essential to involve students not only in goal setting but also in other phases of the lesson. Today a school is not merely a place where knowledge is transferred; it is an establishment that supports the development of a mature personality. Therefore, it is important to teach students how to set their own learning goals. Students should understand why they learn and which phases they have to pass in order to reach their final goals and how to set shortand long-terms aims.

The evocation phase is also important for attracting attention, which is an essential stage of the learning process. The attention process is a temporary inner state, which is called 'mental evocation'. This can be activated by external stimulation. The teacher can use different techniques to capture his/her students' attention. One option is to use various stimulating features of study materials, e.g., students' attention can be captured, by writing on the blackboard with different coloured chalks. Changes in the voice and intonation can also prepare students for new information. Moreover, attention can be seized by visual stimuli or surprises (Gagné \& Driscoll, 1992; Krull, 2000; Lindgren \& Suter, 1994). Evocation helps students to focus their attention; it raises their curiosity and interest and motivates them to participate actively in the lesson. The teacher who decides to omit the evocation phase because of time restraints and a "serious" attitude to work, will inhibit the motivation of his/her students and might not be very successful in the learning phase of the lesson.

\section{Theoretical Aspects of Reflection in the Learning Process}

The term "reflection" was first used by the educationalist John Dewey, who wrote about the importance of reflection in teaching and learning at the beginning of the 20th century. He defined reflective thinking as "active, persistent, and careful consideration of any belief or supposed form of knowledge in the light of the grounds that support it and the further conclusions to which it tends" (1933, p.9). Dewey also stated in his work, "We do not learn from experience. We learn from reflecting on experience" (p.78).

Reflection includes all the activities that help the individual to analyse the situation and observe the process as a bystander (Forsyth, Jolliffe \& Stevens, 1995; Krips, 2003). Reflection enables students to assess their activities; it teaches students to learn by themselves and motivates them for future work. Reflection is the last stage of learning, where the learner expresses his/ her knowledge in his/her own words. During reflection, conclusions are made about learning (reinforcement), feedback is given and gained (Steele et al., 1998).

Self-evaluation is a process through which people learn to observe and assess their own strategies and accomplishments. Psychologically speaking, self-evaluation supports meta-recognition processes. When students exhibit something as a result of learning, they notice that they have reached the expected goals. Such informational feedback is important for reinforcement. The expectations formed at the beginning of learning will be confirmed in the reflection phase (Gagné \& Driscoll, 1992; Pollard \& Triggs, 2001).

The most important part of reflection is feedback, a term that has been defined by many authors. Lindgren and Suter (1994) state that, "feedback is information about performance" (p.199). Sometimes it is possible to give feedback through the students' own activities. In other cases, the teacher has to give a particular answer to secure the necessary feedback. The informational character of feedback is critically important when supporting learning (Gagné \& Driscoll, 1992). Feedback is most efficient when it follows the act immediately and depends on the character of the act. Some tasks have evident feedback options, like a solution to an algebra equation is a whole number. It is important to make sure that the feedback given by the teacher 


\section{PROBLEMS \\ OF EDUCATION \\ IN THE $21^{\text {st }}$ CENTURY \\ Volume 41,2012 \\ 64}

is related to the activity ("the answer is correct"), not the person ("what a smart student").

"Feedback should be given in such a way that students will maintain interest towards their work and will not shift away from the main task." (Lindgren \& Suter, 1994, p.362)

Feedback helps to raise the student's self-esteem and is valuable recognition for a student. Students should gain self-evaluation skills during the learning process to develop self-esteem. Giving concrete feedback, avoiding general judgement and starting from what is important for a student, the latter can more easily accept success, connect it to himself/herself and through that, develop his/her self-esteem. Feedback helps to correct mistakes and motivates the student, giving them the feeling that they have succeeded. Students must be informed about their success, but also about failure. In addition, they should be advised about how to overcome their shortcomings (Fisher, 2004; Liimets, 1998; Mathews et al., 2008). The best forms of feedback give students a belief in themselves, their learning capabilities and skills.

It is important to involve a student in the reflection phase by asking him/her to evaluate the learned material. While doing a task, a student should be able to analyse his/her qualities/ peculiarities, determine the approximate time needed to solve the problem; decide how many times he needs to repeat the material (based on prior knowledge), foresee difficulties that might occur (e.g. poor concentration, fatigue, but also additional external factors) (Kadajas, 1996; Liimets, 1998).

\section{Different Forms of Feedback}

Maslow's theory (2007) indicates that besides primary (physiological) needs there are important social needs: the need for safety, the need for being a member of a group, and the need for love and recognition. In order to fulfil the intellectual needs, all lower needs on the scale should be met. Therefore, according to Maslow's theory, a teacher's recognition is very important to a student. A need for self-actualization can be regarded as the final goal of education - the ability to use one's own potential to the full. Efficient classwork and school life are possible when teachers and students feel safe, they feel they belong, they are loved and respected, and their school experience enables them to move towards self-actualization (Pollard \& Triggs, 2001).

In the modern learning process it is important that students receive oral or written feedback about their subject knowledge, skills, behaviour, attitudes and values either from the teacher, their peers or through self-evaluation. Feedback is not always the same; it has different forms and outcomes. Several authors have described different feedback forms. Lindgren and Suter (1994) point out the following: evaluation, recognition, praise, marks and assessment. Fisher (2004) states that forms of feedback include oral praise, evaluation, prizes and rewards. Burden \& Byrd (1999) emphasize that awards should not be everyday feedback forms because they do not support inner motivation and hinder students' interest in activities. Kadajas (1996) classifies feedback forms as non-verbal assessment (look, nod, smile, etc.), verbal assessment, and numbered assessment (marks).

Assessing students and recognizing their work can strongly influence their motivation. Assessment that is too productive might cause hopelessness. Inappropriate public comparison might also cause a decrease in motivation (Krull, 2000). When the student does not get substantive feedback together with a mark, he/she cannot take much responsibility for his/her learning. Therefore, one of the most important components of grading is giving verbal feedback as well. Verbal feedback supports a student's will to learn more efficiently. It is also the most effective way to support a learner's development and ensure success in learning.

Praise is one of the most efficient forms of recognition that a teacher can use. Praise improves relations between students and a teacher, which in turn supports good behaviour and also improves academic performance in the classroom. Different researchers have pointed out 
that teachers tend to blame more than praise and that they notice faults more easily than virtues. Praise nourishes the soul and makes students strive for more. Students need feedback about their efforts and also feed forward, which helps them establish what leads them to further success and repeated praise. Praise acts as an endorsement only if it is sincere, spontaneous, appropriate to the form and extent of a student's performance, takes into consideration the preferences of the praised, and describes or explains what exactly is worthy of praise. Students need praise and recognition for their efforts according to their abilities. If we have not praised them at the proper moment, permanent reluctance against school might be formed (Krull, 2000; Lindgren \& Suter, 1994; Õunapuu, 2003).

Evaluation should focus on students' positive results. Focusing on the positive helps the student to maintain interest and courage to deal with his/her future efforts and cope with difficulties. However, this does not mean that mistakes and flaws should not be responded to. When evaluating, we should bear in mind that we should not compare a particular student's results with the best results in the class, but with that student's previous results (Sarv, 1999; Türbsal, 2004).

Here are some examples of oral evaluation by Sarv (1999):

- You have finished your work correctly today.

- It is properly done, but...

- $\quad$ Today you have succeeded in ... better than in the previous lesson. However...

- If you were to do it again, it would be much better.

When focusing on mistakes or flaws, it is important that the student him/herself identifies them. Guiding questions can be useful here, the kind of questions which support the development of a student's self-analysis skills. For example:

- Do you think this is ready now?

- Don't you think it is possible to go on with it and make it even better?

- What would your work be like if you had not rushed?

In addition to oral evaluation, there is the possibility to give written feedback. Written feedback should be respectful, adequate and take a student's individuality into consideration. One or two-worded evaluations should be avoided. When assessing in a written form, how the student reads and understands the evaluation should be considered. Here are some examples of written feedback by Sarv (1999):

- You have really tried hard!

- $\quad$ A nice picture, but you missed some spots when colouring. In your next work you will surely be more attentive.

During assessment, teachers should balance students' failures with positive expectations. Students' capabilities should also be stressed in order to maintain their motivation.

Assessing is a systematic gathering and analysis of information about a student's development and giving him/her feedback. Assessment is an inseparable part of everyday schoolwork. The 2010 Estonian National Curriculum for Basic Schools states that the aims of assessment are:

- to support the development of a student - to give feedback, to inspire a student to study according to his/her learning goals, to support the development of a student's selfesteem and assist a student in his/her future educational choices;

- to guide the activities of a teacher in supporting a student's learning and individual development;

- to serve as a basis for transferring students to the next form and deciding about their graduation. (Põhikooli riiklik õppekava, 2010)

It is important to involve students in the evaluation process, to develop their goal-setting skills and assess their own learning according to these goals, and raise their learning motivation.

The 2010 National Curriculum for Basic Schools stresses the importance of formative 
PROBLEMS

OF EDUCATION

IN THE $21^{\text {st }}$ CENTURY

Volume 41, 2012

66

assessment. Formative assessment is evaluation in the course of the learning process, during which a student's knowledge, skills, attitudes, values and behaviour are assessed, feedback is given about the student's results, he/she is encouraged and assisted in his/her further learning and future goals are planned. Formative assessment focuses primarily on the comparison of a student's development to his/her earlier performance. The feedback given describes, as accurately as possible, a student's strengths and weaknesses and contains proposals for future activities that support the student's development. (Ibid.)

The analysis made in the frames of OECD (2005) research indicates that teachers who apply formative assessment are better prepared to consider the individual needs of different students, using various study methods and achieving better results from students who possess different levels of knowledge.

Taking the above-mentioned into consideration, it can be said that it is not important which feedback form a teacher uses but it is essential that these forms are diverse and relevant. Teachers should use methods that activate students to participate in the reflection phase. Reflection is a necessary lesson phase for everyone, both the teacher and students, because it gives each student a chance to experience success and reach their goals. For teachers the reflection phase is substantial for it helps in understanding how well students managed and how they were feeling in the learning process.

\section{Evocation and Reflection Cards}

Evocation and reflection in everyday school-life can be conducted both orally and in a written form. Oral evocation and reflection can be supported by the usage of innovative evocation and reflection cards, the relevance of which was studied by the authors during this research. Ninety-six different evocation and reflection cards were designed and can be used at all school levels, but preferably starting from Form 4. Published by Koolibri, an Estonian publisher, during the winter of 2010, these cards are being used in many Estonian schools today.

The idea to design such cards came after examining the practice portfolios of senior students of Tallinn University Haapsalu College. The portfolios showed that college students have many problems mainly with setting goals for the lesson as well as with receiving and giving feedback.

The aim of the designed cards is to offer teachers support in engaging students in the evocation and reflection phase, enabling students to set their own goals and analyse themselves. The value of the cards lies in the fact that students are given an opportunity to take responsibility for their own studying. While using evocation and reflection cards, the teacher creates a situation where a student is actively involved in the evocation and reflection phase, because every student gets a card with a certain task and has to give his/her opinion, which is regarded important - all this guarantees meaningful learning.

The cards are divided as follows:

1) question cards that support the understanding of questions and develop the skill to answer questions both briefly and in full sentences, and the explanation skill;

2) open-ended sentence cards that support expression of thoughts in full sentences, because the student has the beginning of a sentence and his/her task is to finish it appropriately;

3) word/phrase cards that develop the student's creative expression skills, because the student has only two words/phrases and his/her task is to form one or two sentences with these words/phrases.

Illustrations on the reverse side of the cards include the following: coats of arms of 15 Estonian counties and three major cities; traffic signs; flags of nearby countries, the European 
Union, United Nations and NATO; pictures of animals and birds listed in the Estonian Red Book; folk costumes and symbols of the Estonian Republic. Illustrations on the cards serve an educational purpose and are connected to the 2010 National Curriculum for Basic Schools, which specifies that a student honours and values his/her home, country, nation and culture and knows its symbols.

Before using the cards, it is essential to explain the method to the students: "Now, I will give you one card that has a question, a beginning of a sentence or two words/phrases about today's lesson. When you have received the card, read it silently and think about how to answer, finish the sentence or which sentence(s) to form." If the method is new, students should be asked if they understand what to do and, if needed, they could explain what they are going to do. It is also important to encourage students to express their opinion: "There are no right or wrong answers; be active and honest." It is also important to offer help in case the method is unfamiliar: "If you need help, raise your hand and I will come to you." Depending on the time planned for the cards, the teacher could ask the opinion of all students or only some of them, but different students should have a chance to speak.

Here are some guidelines for using the designed evocation and reflection cards in the classroom:

- The teacher delivers the evocation cards after informing students about the topic of the lesson and before or after clarifying goals and activities. The teacher asks students to answer the question, finish the sentence or form sentences with the given words/ phrases, taking into consideration their feelings, the discussed topic, activities and goals. Then the whole class, together with the teacher summarizes the opinions.

- Different goals and students' expectations should be noted. They may be written on the board in order to check at the end of the lesson if the goals were reached and which ones will be left for the next lesson.

- The teacher delivers the reflection cards to students in the reflection phase and asks them to answer the questions, finish sentences or form sentences with the given words/ phrases, taking into consideration their feelings and work done during the lesson. After that, the class and the teacher summarize the opinions.

- Attention should be paid to what was learned and how and why this is important. To get an overview, students' opinions could be written on the board.

- If needed, the students have the possibility to set new goals and offer their solutions about how to do things better.

How to use evocation and reflection cards in the learning process depends on the students' potential and personalities. The use of these cards is unlimited. In addition to the described method, students can pick the cards themselves from a teacher's table; cards could be hidden in the classroom, and every student encouraged to find one, and when answering the questions or forming sentences, creativity could be supported by encouraging students to act or use pantomime, etc. When the method becomes familiar, students could say what questions they would write on the cards, what kind of illustrations they would use, what else could be done with the cards, or how they might change the cards.

\section{Methodology of Research}

After designing the evocation and reflection cards, testing was carried out. The purpose of testing was to clarify:

- how effective the usage of evocation and reflection cards is in supporting students in setting goals and analysing their activities;

- how applicable the goals for evocation and reflection cards are;

- what problems might occur during the use of evocation and reflection cards. 


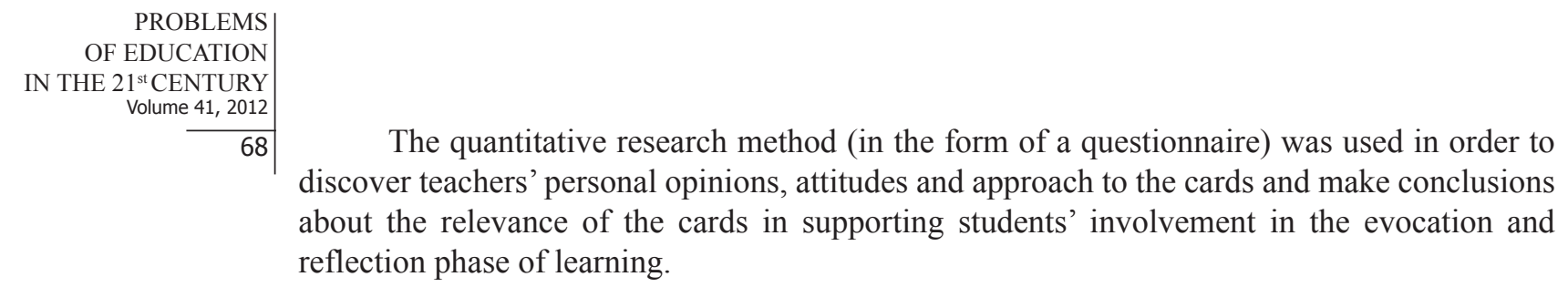

Instrument

The data collection instrument used was an anonymous questionnaire that was drafted based on the theoretical material and the concept of evocation and reflection cards. The questionnaire consisted of 23 statements and 3 open questions, to determine the relevance of evocation and reflection cards, applicability of the set goals and problems rising from the use of the cards. The questionnaire was divided into four blocks. The first block included questions about the teachers' background, gender, age, level of education and pedagogical experience. In the second block, teachers were asked to evaluate the importance of students' involvement in the evocation and reflection phase. The third block included statements about the applicability of goals set for evocation and reflection cards. While forming these statements, the viewpoints of different authors and several factors related to evocation and reflection cards were taken into consideration. Every statement had to be evaluated according to the respondent's opinion in the Likert scale: fully disagree, rather do not agree, cannot say, rather agree, or fully agree. The fourth block included three open questions that explored the teachers ' personal opinions about the cards. The purpose of these questions was to gather more detailed information about the usage of the designed cards. At the end of the questionnaire, the teachers were given a chance to add other comments on the topic. A cover letter was added to the questionnaire.

\section{Sample and Procedures of Research}

The research was conducted during the period from January to February 2011 in three different counties of Estonia (Harju, Lääne, Pärnu). The target group consisted of class-teachers and their students. The schools were selected from the list of co-operation partners (practice schools) of the teacher training department of Tallinn University Haapsalu College. Every chief of staff was contacted by e-mail and the list of teachers who agreed to participate in the research was drafted. Evocation and reflection cards were delivered to schools and the usage of cards in the learning process was introduced, clarification questions were answered and the aim of the research was explained. In total, 24 teachers from 5 schools agreed to test the cards during a one-month period.

After the testing period, questionnaires were delivered to schools and the deadline for responses was fixed. Questionnaires were given to 24 teachers, but only 13 returned them, i.e. $54 \%$ of the participants. The authors believe that such a low participation level might have been due to the fact that teachers are not aware of the importance of evocation and reflection in the learning process or that they do not know how to use this kind of card in the classroom. Participants who did not answer the questionnaire were contacted several times via e-mail or telephone. Some teachers did not answer the questionnaire because they did not know how to use the cards in the learning process and did not understand their effectiveness, i.e. why it is important to engage students in the evocation and reflection phase of the lesson. In addition, assumptions can be made that the questionnaires were not returned because preparatory work with teachers was not efficient, teachers did not have enough interest to test a new method or they regarded it as additional work on top of their many other duties.

The following description of the sample is based on the data of 13 teachers. All teachers who participated in the research were female and had pedagogical higher education. One teacher was aged less than 25, seven teachers were 26-40 years old, four teachers 41-55 years old and 
one teacher was older than 55. Three teachers had worked as teachers for less than 5 years; two teachers had 6-10 years of work experience; three teachers had 11-15 years and four teachers had 21-25 years of work experience. One teacher stated that her work experience was more than 26 years and no teachers had 16-20 years of work experience.

The answers of the teachers and comments on the questions are presented in italics under the research results. The answers of teachers were partly edited - repetitions were excluded and vague formations clarified. Answers to the statements and questions in the questionnaire are presented in quotation marks.

\section{Results of Research}

In the second block of the questionnaire, teachers were asked to evaluate the importance of evocation and reflection and students' involvement in those phases. Three statements were presented to the respondents. Twelve (12) teachers "fully agreed" with the statement that "evocation and reflection are important for the learning process" and one (1) teacher answered, "rather agree". Ten (10) teachers "fully agreed" with the statement, "involving students in the goal setting and reflection of the lesson is important". Three teachers answered, "rather agree". According to the above-mentioned results, it can be concluded that teachers are aware of the importance of evocation and reflection and acknowledge the importance of involving students in these phases of the lesson.

In the third block of the questionnaire, teachers were asked to evaluate the applicability of the goals set for the evocation and reflection cards during the test period. Twenty (20) statements were presented to the teachers. All goals were responded to as "fully agree" and "rather agree" rather than "cannot say" or "rather do not agree". The answer "fully disagree" was never given. In most cases (13) the respondents agreed with the following statements:

- "Using evocation and reflection cards helps develop students' self-expression skills",

- $\quad$ "The cards develop the student's analysis and explanation skills",

- "The cards activate students",

- $\quad$ "Reflection cards help students to summarize the learned material" and

- " "They help students to analyse themselves as well as the learning process".

To some extent (in 1 or 2 cases) teachers hesitated in the following statements:

- "While using evocation and reflection cards, students lead their own studies",

- "Students experience success",

- "Students take responsibility for their learning" and

- "Students improve different study skills".

We can conclude from these results that the goals set for the designed evocation and reflection cards are partly applicable.

In the fourth block of the questionnaire, three open questions were presented in order to gather more detailed information about the topic. The first question asked was: "What is your opinion of the efficiency of evocation and reflection cards in the learning process?" The following responses, among others, were given:

- The test period was too short. I wanted to try the cards with all my students. In the beginning, the cards took up too much lesson time, but I believe that the more I use them, the greater their efficiency.

- I think that evocation and reflection cards are really effective.

- $\quad$ Those cards really support, encourage and inspire students.

- I have just had a brief look at the cards and I do not feel secure working with them.

- I think very positively about the cards, because they made my students active, supported classroom discipline, helped to keep thoughts on the topic. I especially liked the fact 
PROBLEMS

OF EDUCATION

IN THE $21^{\text {st }}$ CENTURY Volume 41, 2012

70

that students took all their answers seriously, they started to explain their opinions. It was a surprise to me that using the cards did not take up so much time at the beginning and end of the lesson.

- $\quad$ The cards make students set goals for their actions, also help them summarize. This process should be started in Form 1; then the children will get used to this type of activity.

- The cards help to establish immediate co-operation between the students and the teacher. Students' self-expression skills develop.

In the responses to the first question, the teachers pointed out that too little time for testing was a problem and in the beginning the cards took up too much lesson time, but after a while their use became less time-consuming. It was also mentioned that it would be good to start using the cards with younger students because the older ones lack the experience. This comment suggests that teachers do not use learner-centred evocation and feedback and as a result students are not used to setting goals and analysing their learning.

Among different positive aspects, teachers mentioned that the designed evocation and reflection cards provided opportunities for teacher-student co-operation, supported classroom management as well as setting goals and analysing the lesson. The cards helped the students to keep focused on the material, encouraging them to think about the answers and explain their opinions. According to teachers' responses, it can be concluded that the efficiency of evocation and reflection cards in the learning process was proved by the research.

The second question, "How much do evocation and reflection cards support students' skills to set goals and analyse their learning process?" delivered the following responses:

- Surely the cards support and help. One reason is probably that the students have to think about the topic; every card requires different answers. Students are not allowed to repeat the answers that have already been mentioned.

- $\quad$ The benefit of the cards became especially evident in the reflection phase - students gave immediate feedback.

- More active students are motivated for sure, but there are slower students in the class and if we have to work together, it hinders the pace of the lesson.

- As I used the cards a lot and in many different subject lessons and different classes (Estonian, maths, nature sciences, art, IT and social lessons), I think that they really support students'learning. It appeared that it was more difficult for them to set goals, but a lot easier to analyse their work.

- I could answer that question better if I had more time to use the cards. Then I could have seen how they support the child. My first impression is positive.

- I think they support learners a lot. Every student has understood that. There is a noticeable change when comparing students before and after using the cards. The students are more daring in explaining their answers and they can also accept other people's explanations better.

- Evocation and reflection cards do support the learning process. But younger pupils (Form 1) may experience difficulties in using the cards because their wording may be a bit too vague.

The responses show that evocation and reflection cards support the students' skills to set goals and analyse their learning process. The cards help students to think about the material they have learned and give immediate feedback. They also support the formation of a student's individual opinion; because every card requires a different answer, the student cannot use a previously offered opinion.

The third question asked was: "What are your proposals regarding these evocation and reflection cards?" Teachers gave the following responses:

- $\quad$ These cards should be explained to teachers in more detail. 
- $\quad$ There is no point in using the cards in every lesson, but when there is an important topic, they are great.

- $\quad$ They should be used more broadly.

- It is better to use one card at a time and discuss it with the whole class. Then it is more effective.

- Using the cards must be recommended to everyone!

- Very good and necessary cards. Already perfectly usable in Form 2. I also tried them with my Form 1, but the definition of a goal is a bit complicated for them. I will try again during the fourth quarter.

Most of the responses emphasized that the designed evocation and reflection cards deserve more attention and should be introduced to all teachers. All respondents recommended that their colleagues apply this method in the learning process. In addition, it was mentioned that it would be more efficient to rely on one card during one lesson and discuss the matter together with the whole class. On the whole it can be concluded that evocation and reflection cards are effective in the learning process and the usage of these supports a student's capability to set goals, manage and analyse his/her own learning.

Other comments included:

- I also used the pictures on the cards (e.g. while dividing students into groups).

- Children are very creative and use the cards in different ways. For example, while forming pairs or groups.

- Some students overcame their fears in defining goals or expressing their success stories. Using cards also supported the formation of sentences. Students said that the cards also develop 'fantasy'.

- I used reflection cards in Form 2. As I have already been using formative assessment for two years in this class, it was very interesting for my pupils. What I liked very much: evocation and reflection cards make students think, analyse and strive for more. There were cases when they could not give feedback, so we tried to find an answer together with the whole class. This is a development process that goes on through the whole learning period. New goals are constantly set, implemented, analysed and success enjoyed.

- I am surprised that the change in students was really remarkable, especially in those who have had learning difficulties. It was quite unexpected for me when a child suddenly asked, "What's the use if I write down whether and how I studied for the test?" That shows how strong the belief is that students get feedback only from a teacher. They are not used to analysing themselves. It seems complicated and strange for them.

It can be concluded from the above-mentioned that evocation and reflection cards are applicable in different learning situations and subjects. Moreover, as the cards are quite new in the classroom, both teachers and students need more adaptation time to get used to the method.

\section{Discussion}

The answers to the open questions indicate three major problems that occurred during the use of cards: (a) time spent on using the cards, (b) setting goals for one's learning is unfamiliar to students, and (c) differing levels of students. It was mentioned by the respondents that, as the method is new, the cards take up too much valuable lesson time, but when the method becomes more familiar, less time is spent on it. In addition, the teachers said that all the students do not need the cards to set goals and analyse their learning. It was also mentioned that goal setting is difficult and there is a strong belief that feedback should only be given by the teacher. Students are not used to analysing themselves. Thus, the cards should be introduced in the first grades, so 


\section{PROBLEMS \\ OF EDUCATION \\ IN THE $21^{\text {st }}$ CENTURY Volume 41, 2012 \\ 72}

that pupils can practise goal setting and self-analysis from the very beginning. This agrees well with the study of Waddington and Wright (2007), who also stressed that promoting reflection already at an early stage in the learning process is very important.

All the problems revealed in the study refer to the novelty of the method because both students and teachers are not used to using evocation and reflection cards. Students find it difficult to set goals and give feedback, and teachers do not know how to apply the method so that it supports their students' learning. This is consistent with the research literature (Gustafson \& Bennett, 2002; Stevenson \& Willott, 2008) that generally indicates that reflection is difficult to accomplish. Both students and teachers need practice and guidance to develop reflective skills.

Time issues, regarding the usage of cards, as well as problems related to different levels of students can be solved by following the concept of evocation and reflection cards, which clarifies the point that not all students have to express their opinion in every lesson. More important is the fact that students could think individually and when using the cards, the potential of learners is something to be taken into consideration. It is not important whether the student can set goals and analyse his/her learning without these cards; the important thing is that he/she does so in the lesson. Evocation and reflection cards could assist even an academically strong student and offer necessary support. The earlier studies (Gustafson \& Bennett, 2002; Stevenson \& Willott, 2008) also confirm that educators and trainers see reflection as a desirable activity for learners to engage in, because reflection results in enhanced learning.

The authors of the research believe that evocation and reflection cards are a support aid that helps to familiarize students with goal setting and self-analysis. The cards enable students to assess their activities and motivate them for future work.

\section{Conclusions}

Efficient evocation gives a student the possibility to set goals for him/herself; activates existing knowledge, focuses attention and raises motivation. Reflection provides the possibility for feedback that is important for the development of self-reflection skills. Giving feedback and receiving it develops a student's self image, motivates him/her to participate in the learning process and also develops study skills. It is important to link feedback to every lesson because the feeling of success acts as a motivator for the future.

The relevance of evocation and reflection cards depends greatly on a teacher's opinion and will to use them. If a teacher does not possess enough knowledge about how to involve students in goal setting and analysis of the lesson, the efficiency of these cards is not evident. Thus, it is necessary to create additional instructional materials that would help teachers to involve students more in the evocation and reflection phase.

One of the limits of this research is obviously the sample size; and therefore, the results are representative only of the teachers who participated in the study. It is necessary to conduct a more broad-based study with a larger sample size, including both teachers and students, to determine the real effect of the evocation and reflection cards on the learning process.

Estonian teachers have only recently started to more acknowledge the importance of learner-centered goal setting and reflective learning; therefore, the introduced method was not familiar to them. Now that the evocation and reflection cards have been used in different Estonian schools for more than a year and teachers have had more experience with the cards, it would be interesting to know how their perceptions of and attitudes toward reflective practice have changed. 


\section{References}

Burden, P. R. \& Byrd, D. M. (1999). Methods for effective teaching. Needham Heights, MA: Allyn \& Bacon.

Crawford, R., Mathews, S. R., Makinster, J. \& Saul, E. W. (2005). Teaching and learning strategies for the thinking classroom. New York, NY: Open Society Institute.

Dewey, J. (1933). How we think: A restatement of the relation of reflective thinking to the educative process. Lexington, MA: Heath.

Eesti Koostöö Kogu. (2010). Eesti inimarengu aruanne 2009. Retrieved 21/01/2011, from http://www. kogu.ee/public/eia2009/EIA_kokkuvote09.pdf.

Fisher, R. (2004). Õpetame lapsi õppima. Tartu: AS Atlex.

Forsyth, I., Jolliffe, A. \& Stevens, D. (1995). Evaluating a course: Practical strategies for teachers, lecturers and trainers. London: Kogan Page.

Gagné, R. M., \& Driscoll, M. P. (1992). Õppimise olemus ja õpetamine. Tartu: Tartu Ülikooli Kirjastus.

Gustafson, K. L., Bennett, W. (2002). Promoting Learner Reflection: Issues and difficulties emerging from a three-year study. Retrieved 04/03/2012 from http:/www.dtic.mil/cgi-bin/ GetTRDoc?AD=ADA472616.

Kadajas, H. M. (1996). Õpitulemuste hindamise probleeme ja põhiseisukohti. In H.-M. Kadajas (Ed.), Hindamine: Probleeme ja lahendusi (pp. 6-8). Tallinn: Eesti Vabariigi Haridusministeerium.

Kidron, A. (1999). 122 opetamistarkust. Tallinn: Andras \& Mondo.

Klooster, D. J., Steele, J. L. \& Bloem, P. L. (2001). Ideas without boundaries: International education reform through reading and writing for critical thinking. Newark, DE: International Reading Association.

Kolb, D. A. (1984). Experiential learning: Experience as the source of learning and development. New Jersey: Prentice-Hall.

Krips, H. (2003). Suhtlemisoskusest õpetamisel ja juhtimisel. Tartu: Tartu Ülikooli Kirjastus.

Krull, E. (2000). Pedagoogilise psühholoogia käsiraamat. Tartu: Tartu Ülikooli Kirjastus.

Liimets, H. (1998). Kuidas õppeprotsess kasvatab? Tallinn: TPÜ Kirjastus.

Lindgren, H. C., \& Suter, W. N. (1994). Pedagoogiline psühholoogia koolipraktikas. Tartu: Tartu Ülikooli Kirjastus.

Maslow, A. H. (2007). Motivatsioon ja isiksus. Tallinn: Mantra Kirjastus.

Mathews, S. R., Löfström, E. \& Poom-Valickis, K. (2008). Psühholoogia klassiruumis. Tallinn: Tallinna Ülikooli Kirjastus.

Organisation for Economic Cooperation and Development. (2005). Formative assessment - improving learning in secondary classrooms. Retrieved 30/01/2011, from http://www.oecd.org/ dataoecd/19/31/35661078.pdf.

Organisation for Economic Cooperation and Development. (2007). PISA 2006 Science competencies for tomorrow's world: Executive summary. Retrieved 21/01/2011, from http://www.oecd.org/ dataoecd/15/13/39725224.pdf.

Pollard, A., \& Triggs, P. (2001). Reflektiivõpe keskkoolis. Tartu: Tartu Ülikooli Kirjastus.

Poom-Valickis, K. (2007). Kuidas kavandada kutsealast arengut. In E. Eisenschmidt (Ed.), Õpetaja kutse professionaalne areng ja eneseanalüüs (pp. 21-27). Tallinn: Vali Press.

Puksand, H., Lepmann, T., \& Henno, I. (2010). PISA 2009 - Eesti tulemused. Tallinn: Riiklik Eksami- ja Kvalifikatsioonikeskus. Retrieved 21/01/2011, from http://www.ekk.edu.ee/vvfiles/0/PISA_ 2009 Eesti.pdf.

Põhikooli riiklik õppekava. (2010). Riigi Teataja. Retrieved 30/01/2011, from https://www.riigiteataja. ee/akt/13273133. 
PROBLEMS

OF EDUCATION

IN THE $21^{\text {st }}$ CENTURY

Volume 41,2012

Sarv, E. S. (1999). Sõnaline hindamine I kooliastmes. In E. Kulderknup \& U. Auli (Eds.), Hindamine: Probleeme ja lahendusi II: materjale klassiõpetajatele ja emakeeleõpetajatele (pp. 4-29). Tallinn: Eesti Vabariigi Haridusministeerium.

Steele, J. L., Meredith, K. S., Temple, C., \& Walter, S. (1998). Lugemine ja kirjutamine iseseisva mõtleja kujunemiseks. Käsiraamat I. RWCT project.

Stevenson, J., Willott, J. (2008). Attitudes towards Reflective Practice: Emerging findings from a TQEF study. The Assessment, Learning and Teaching Journal. 3. pp. 46-50. Retrieved 04/03/2012 from http://www.leedsmet.ac.uk/ALT_Journal_No_3.pdf.

Türbsal, L. (2004). Õpetaja roll lapsekesksuse põhimõtteid rakendades. In E. Kulderknup (Ed.), Õppe- ja kasvatustööst I kooliastmes (pp. 23-26). Tallinn: Argo.

Vaughan, J. L., \& Estes, T. H. (1986). Reading and reasoning beyond the primary grades. Boston, MA: Allyn \& Bacon.

Waddington, S. B., Wright, P. N. (2007). Student Reflection: An 'ideal world'? Planet. 18. pp. 51-54. Retrieved 04/03/2012 from http://www.gees.ac.uk/planet/p18/sw2.pdf.

Õunapuu, T. (2003). Õpetamiskunsti viidad. Tallinn: Koolibri.

Advised by Leida Talts, Tallinn University, Tallinn, Estonia

Received: January 24, 2012

Accepted: March 10, 2012

Sirje Piht

Doctoral Student, Lecturer of Didactics and Head of the Teacher Training Department, Tallinn University Haapsalu College, 12 Lihula Road, 90507 Haapsalu,

Estonia.

E-mail: sirje@hk.tlu.ee

Website: http://www.hk.tlu.ee

Piret Lehiste

MA, Lecturer of English, Tallinn University Haapsalu College, 12 Lihula Road, 90507 Haapsalu, Estonia.

E-mail: piret@hk.tlu.ee

Website: http://www.hk.tlu.ee

Rea Raus

Doctoral Student, Head of Staff Development and Staff Mobility, Tallinn University, 25 Narva Road, 10120 Tallinn, Estonia.

E-mail: rearaus@tlu.ee

Website: http://www.tlu.ee

Mariliis Lazarev

MA, Elementary School Teacher, Salme Basic School, 1 Kuressaare Road, 93201

Salme, Saaremaa, Estonia.

E-mail: mariliis.lazarev@mail.ee

Website: http://www.salme.edu.ee 